\title{
Perceived Impact of Entrepreneurship Education on Career Development among Undergraduates in South-South Universities in Nigeria: Implication for Counselling
}

\author{
Grace Omejevwe Akpochafo ${ }^{1} \&$ Ijeoma Henrietta Alika ${ }^{2}$ \\ ${ }^{1}$ Department of Guidance and Counselling, Delta State University, Abraka, Delta State, Nigeria \\ ${ }^{2}$ Department of Educational Evaluation and Counselling Psychology, Faculty of Education, University of Benin, \\ Benin City, Edo State, Nigeria \\ Correspondence: Grace Omejevwe Akpochafo, Department of Guidance and Counselling, Delta State University, \\ Abraka, Delta State, Nigeria.
}

Received: December 14, 2017

Accepted: January 28, 2018

Online Published: March 8, 2018

doi:10.5539/jel.v7n3p102

URL: https://doi.org/10.5539/jel.v7n3p102

\begin{abstract}
This study investigated the perceived impact of entrepreneurship education on career development among undergraduates in south-south universities in Nigeria. To guide the study four research questions were generated and one hypothesis formulated, which was tested at 0.05 level of significance. The study employed an expost facto research design. The population of the study consists of all undergraduates in south-south universities in Nigeria. Sample size consists of 150 students who were randomly drawn and who had undertaken entrepreneurship studies. The main instrument for the study was a questionnaire titled Entrepreneurship Education and career development scale (EECDS). Data was analyzed using descriptive statistics for the research questions and t-test for hypothesis. The result showed that there are inadequate facilities and effective teaching and learning of entrepreneurship education in Nigerian universities. Moreover, it was also found that the students were of the view that entrepreneurship education will provide training that would make undergraduates creative and innovative if the programme is properly implemented.
\end{abstract}

Keywords: entrepreneurship education, career development, undergraduates, universities, counselling

\section{Introduction}

Nigeria views education of her citizens as a means for the realization of her desires of having a strong and self-reliant nation. Moreover, the government sees the education of her citizens as a means of acquiring appropriate skills, abilities, competencies and the right type of values for their survival and the survival of the Nigerian society. However, despite these laudable views in the last 3 decades, according to Inegbenebor \& Igbinomwanhia (2011), Nigeria has earned over three hundred billion dollars from oil sales; this has not been reflected in the standard of living of her citizens. The country is among the poorest countries of the world and among the underdeveloped nations of the world. Studies indicate that about $80 \%$ of Nigerian graduates are unemployed (Adejimola \& Olufunmilayo, 2009), no wonder the government introduced entrepreneurship education in 2006 into the curriculum of tertiary education in the country and made it compulsory irrespective of an area of specialization. This is with a view to ensuring that undergraduates are equipped with relevant skills that may facilitate self-survival and self-employment. The major goals of any nation are geared towards the economic empowerment of her citizens, hence the government anticipated that by 2010, 50,000 graduates who would have gone through the system are entrepreneurial skilled and with $5 \%$ of them being self-employed and self-reliant (Rufai, 2006). Therefore, there is the need to investigate the extent to which entrepreneurship education has impacted on the career development of University undergraduates in South-South Nigeria. There are six states in the south-south geopolitical zone of Nigeria, they include River State, Akwa Ibom State, Bayelsa State, Cross Rivers State, Delta State and Edo State, these states are endowed with oil and gas with huge investment opportunities in tourism and agriculture.

Entrepreneurship Education according to Haase \& Lautenschlager (2011) is an important factor in developing individuals' entrepreneurial motivation, knowledge and skills. An entrepreneur is a risk taker (Ifedili \& Ofoegbu, 2011). Torre (2015) also opined that entrepreneurship is the ability of individuals to undertake risk along with 
factors of production in order to create goods and services. It can be argued also as the readiness and ability of an individual to look for investment opportunities in an environment, and be able to set up a business and manage it effectively.

According to a (2009) publication of the Education Ministry, Finland, entrepreneurship education is a more encompassing concept when compared to entrepreneurship as a practice of business deal. When conceptualized it has to with training and entrepreneurship. According to the same publication the components of entrepreneurship education include an active and resourceful person, an environment conducive to learning, education and training, an active policy that promotes enterprise. Entrepreneurship education generates entrepreneurs at all levels of the society and strengthens and creates business. It is an aspect of lifelong education in which entrepreneurial techniques are developed and replaced as one grows higher. It has to do with life management interaction, self-guided action, a capacity for innovation and an ability and readiness to encounter change. These factors are directed and propelled by education and training (Finland, 2009).

Entrepreneurship education is oriented towards diverse ways of maximizing opportunities and potentials. It tries to furnish students with knowledge, accomplishments and motivation (Ayatse, 2013). The objectives of entrepreneurship education, according to Paul (2005), Ojeifo (2013) and cited in Ayatse (2013) include the following:

- To provide functional education for the youth, which could guarantee self-employment and self-orientation.

- To equip graduates with the requisite training that will assist them in being creative and innovative and also to enable them identify new business opportunities.

- To function as an avenue for the increase and evolution of the economic system.

- To assist in providing risk management training for graduates.

- To get to the minimal high rate of poverty.

- To create employment opportunities for the graduates.

- To lower rural, urban migration.

- To give fresh graduates enough training to make career in small and medium sized businesses.

- To drive into the youth some elements of perseverance for them to succeed in their business pursuit.

- Create a smooth transition from traditional to a modern industrial economy.

According to Ifedili \& Ofoegbu (2011), the entrepreneurship education in Nigerian universities lacks good management and its contents are poor, despite its laudable objectives as stated above. They opined that most of the students do not grasp the importance of the entrepreneurship education course in Nigerian Universities. They further asserted that the content and presentation did not make for easy realization of its objectives.

A nation like Nigeria, which is among the developing countries of the world cannot afford to neglect the relevance of entrepreneurship education if career development of her citizens must be developed optimally and if she must advance or progress technologically. Also, Hannon (2005) opined that current trends reveal "confusion about the roles and impact of entrepreneurship education. Greene \& Saridakis (2007) and Pittaway \& Cope (2007) found that the United Kingdom National Council for Graduate Entrepreneurship accepted that entrepreneurship education and training is characterized by doubt and vagueness about what and how it should be done, hence the need to investigate the impact of entrepreneurship education on career development of undergraduates. Nevertheless studies have shown that students have a positive attitude towards entrepreneurship education in Nigeria (Ekpoh \& Edet, 2011; Bassey \& Olu, 2008). Moreover, Wilson, Kickul, \& Marlino (2007) asserted that entrepreneurship education may arouse students' desire to opt for a career in entrepreneurship education.

Globally, there is a paradigm shift in career choice since the 21 st century; this shift is a new social arrangement of work/career, which demands lots of questions and challenges to career planners and counsellors. Such arrangement has to be lifelong holistic contextual, preventive and skill acquisition oriented, which is somewhat in line with Entrepreneurship Education. Javis (2003) postulated that these skills should guarantee confidence in the clients' ability to exhibit a fulfilling life and at the same time these skills should focus on the following:

- Who the individuals are, what these individuals can afford, and what their priorities are.

- Direction- identifying available options, what things are of interest to them, and how to be eligible for appropriate learning and available jobs. 
- Adaptability- the skill of making the best out of every available opportunity.

- Healthy self-esteem and self-knowledge- prevent uncertainty and doubt.

The above skills can only be imparted through human support in the learning process of which entrepreneurship education is in line with. Therefore, there is the need to investigate the extent to which these skills are exhibited in line with the career development of students as regards entrepreneurship education which no doubt has the sole aim of imparting lifelong skills to the learners. The new career paradigm shift model entails: helping people become healthy, self-reliant, able to cope with constant change and lead the people in a rapidly changing world and at the same time maintain a balance between life and career roles. Sanders (2003) opined that the new paradigm in career choice focuses on who the individual is and indulging in work that they really love, which no doubt enhances productivity. Consequently, a study such as this becomes imperative in that it seeks to investigate the impact of entrepreneurship education on the career development of undergraduates.

Career choice in the new paradigm is explained in terms of skills and values (Straby, 2002). It provides opportunities for individuals to fit into diverse job opportunities based on skills acquired, which demands a high level of self-knowledge and self-confidence both of which are career choice skills. Javis (2003) also opined that the acquisition of more education and skills by an individual may guarantee a great likelihood of access to work/jobs, with good remuneration and job security. Entrepreneurship education is designed to provide skills for self-employment to the individuals. Krumboltz \& Worthington (1999), observed that the determinants of selection and success in life have to do with the acquisition of basic life skills. Consequently, there is a clarion call that educators should teach employable skills that will enable individuals graduate as skilled workers so as to fit into the global trend.

It is important to note that studies have shown that entrepreneurship education in Nigeria has some challenges which include the following according to Ojeifo (2013): as cited in Ayatse (2013).

- Constant political and administrative corruption in conjunction with non-availability of social agreement on macroeconomic policies.

- No provision of vocational centres for skill acquisition for rural and urban youths.

- There are no data banks for entrepreneurship education.

- There are administrative and trade bottlenecks that inhibit human development and the provision of technical assistance.

These challenges notwithstanding, entrepreneurship education has been made mandatory in all tertiary institutions in Nigeria. Thus, there is the need to determine its impact on career development among undergraduates in South-South universities in Nigeria.

\subsection{Statement of the Problem}

With the advent of the paradigm shift in career choice globally in the 21 st century and the introduction of entrepreneurship education in Nigerian universities with the view of equipping the youths with basic life skills along with the acquisition of basic education, $80 \%$ of graduates still roam the streets as unemployed graduates (Adejimola \& Olufunmilayo, 2009). The objectives and goals of entrepreneurship education seem not to be realized in that youths/graduates finish their education and are unable to engage themselves as self-employed persons based on their career choice and on skills acquired while studying entrepreneurship education.

Therefore, if the nation must realize the objectives of setting up this compulsory course in our higher education sector, there is the need to investigate the extent to which the goals have been realized, in line with the career development of undergraduates, especially as regards impacting skills to the undergraduates, in line with the global paradigm shift in career choice. So, could it be said that entrepreneurship education in Nigerian universities is a veritable tool in enhancing career development among undergraduates in South-South universities in Nigeria?

\subsection{Research Questions}

To guide the study the following research questions were generated:

1). To what extent will entrepreneurship education help in the acquisition of skills relevant to students' career choice?

2). To what extent will entrepreneurship education help in ensuring that individuals fit into diverse careers based on skills acquired? 
3). To what extent will entrepreneurship education provide training that will make undergraduates creative and innovative?

4). Are the skills acquired in entrepreneurship education relevant to self-employment?

\subsection{Hypothesis}

There is no significant difference between the University of Benin and Delta State University undergraduates on their views about entrepreneurship education and career development.

\section{Methodology}

The study employed an ex-post facto research design. This design is appropriate because the data was collected from those who have studied entrepreneurial education, which implies after the event under study.

The target population for this study consists of all undergraduates in South-South Universities in Nigeria but the accessible populations were undergraduates in Delta State University and University of Benin. The sample size was made up of 150 students from both Universities who had done entrepreneurial education drawn using simple random sampling.

\subsection{Instrument}

The main instrument for this study was the questionnaire titled Entrepreneurship Education and Career Development Scale (EECDS). It was made up of 20 items. It had a four point scale response format of Strongly Agreed (SA), Agree (A), Disagrees (D) and Strongly Disagree (SD). The Cronbach alpha procedure was adopted in establishing the reliability of the instrument which yielded a coefficient of 0.85 which signifies that the instrument was reliable. The validity of the instrument was ascertained by giving it to experts in the Department of Guidance and Counselling and Measurement and Evaluation who concluded that the instrument was valid as it measured what it was designed to measure.

The instrument was distributed personally to achieve a good return and the data were analyzed using descriptive statistics for the research questions and t-test for the hypothesis. The presentation of data is as follows:

\section{Result}

\section{Research Question 1}

To what extent will entrepreneurship education help in the acquisition of skills training relevant to students' career development?

Table 1. Mean and standard deviation on the impact of entrepreneurship education in acquisition of skills training relevant to students' career

\begin{tabular}{|c|c|c|c|c|}
\hline S/No. & Statement & Mean & SD & Decision \\
\hline 1. & $\begin{array}{l}\text { Entrepreneurship education helps in the acquisition of necessary } \\
\text { skills for self-employment. }\end{array}$ & 3.59 & 0.67 & High \\
\hline 2. & $\begin{array}{l}\text { In my institution, there are enough facilities for entrepreneurship } \\
\text { education. }\end{array}$ & 2.07 & 0.83 & Low \\
\hline 3. & $\begin{array}{l}\text { In my institution, there are enough resource persons to teach } \\
\text { entrepreneurial courses. }\end{array}$ & 2.23 & 0.83 & Low \\
\hline 4. & We take our courses in an entrepreneurial learning environment. & 2.60 & 0.79 & High \\
\hline 5. & $\begin{array}{l}\text { I am actually getting knowledge in my entrepreneurship course of } \\
\text { study, which will help my career growth. }\end{array}$ & 2.78 & 0.85 & High \\
\hline 6. & I have adequate training in my entrepreneurship course. & 1.97 & 0.75 & Low \\
\hline 7. & $\begin{array}{l}\text { The content in the entrepreneurship education course is just okay for } \\
\text { my chosen course. }\end{array}$ & 2.15 & 0.77 & Low \\
\hline
\end{tabular}

From the above table, items 1,4 and 5 with a mean ranged of $2.60-3.59$ shows high extent that was above 2.50 cut-off mark. On the other hand, items 2, 3, 6 and 7 reveals low extent since they were below the cut-off mark of 2.50. Since the low items are more, it can be said that entrepreneurship education does not help in the acquisition of skills training that are relevant to students' career development.

\section{Research Question 2:}

To what extent will entrepreneurship education help in ensuring that individuals fit into diverse careers based on skills acquired? 
Table 2. Mean and standard deviation on the impact of entrepreneurship education in ensuring that individuals fit into diverse career based on skills acquired.

\begin{tabular}{lllll}
\hline $\mathrm{N}=150$ & & & & \\
\hline $\mathrm{S} /$ No. & Statement & Mean & SD & Decision \\
\hline 8. & Entrepreneurship education will make me create job for others & 3.00 & 0.84 & High \\
9. & $\begin{array}{l}\text { Entrepreneurship training will enable students fit into diverse job } \\
\text { opportunities. }\end{array}$ & 2.93 & 0.84 & High \\
\hline
\end{tabular}

Table 2 revealed that items 8 and 9 with a mean ranged of $2.93-3.00$ showed a high extent, which was above the cut-off mark of 2.50. This indicated that, the students were of the view that entrepreneurship education ensured that individuals fit into diverse career based on skilled acquired.

\section{Research Question 3}

To what extent will entrepreneurship education provide training that will make undergraduates creative and innovative?

Table 3. Mean and standard deviation on the impact of entrepreneurship education in providing training that will make undergraduates creative and innovative

\begin{tabular}{lllll}
\hline $\mathrm{N}=150$ & & & & \\
\hline S/No. & Statement & Mean & SD & Decision \\
\hline 10. & The training in entrepreneurship education will make me to be creative. & 3.17 & 0.72 & High \\
11. & The training in entrepreneurship education will enable me to be innovative. & 3.10 & 0.67 & High \\
12. & I am active in entrepreneurship education class and willing to take initiative. & 3.70 & 0.62 & High \\
\hline
\end{tabular}

Table 3, revealed that items 10,11 and 12 with mean ranged from $3.10-3.70$ showed a high extent which was above the cutoff mark 2.50. This implies that, the students were of the view that entrepreneurship education can provide training that will make undergraduates to be creative and innovative.

\section{Research Question 4:}

Are the skills acquired in entrepreneurship education relevant to self-employment?

Table 4. Mean and standard deviation on the extent of entrepreneurship education relevance to self-employment

\begin{tabular}{|c|c|c|c|c|}
\hline \multicolumn{5}{|c|}{$\mathrm{N}=150$} \\
\hline S/No. & Statement & Mean & SD & Decision \\
\hline 13. & $\begin{array}{l}\text { Entrepreneurship education helps in the acquisition of necessary skills for } \\
\text { self-employment. }\end{array}$ & 3.59 & 0.67 & High \\
\hline 14. & $\begin{array}{l}\text { With the skills I have acquired from entrepreneurial studies I can do } \\
\text { something for myself. }\end{array}$ & 2.71 & 0.91 & High \\
\hline 15. & $\begin{array}{l}\text { The skills I have acquired from entrepreneurial education will enable me } \\
\text { to establish a business of my choice. }\end{array}$ & 2.65 & 0.95 & High \\
\hline 16. & $\begin{array}{l}\text { The skills I have acquired in entrepreneurship education will make me to } \\
\text { be self reliant. }\end{array}$ & 2.69 & 0.95 & High \\
\hline 17. & $\begin{array}{l}\text { The skills I have acquired in entrepreneurship education will make me to } \\
\text { be confident. }\end{array}$ & 2.44 & 0.83 & Low \\
\hline
\end{tabular}

Table 4, showed that items $13,14,15$ and 16 with a mean range of $2.65-3.59$ indicated high extent which was above the cutoff mark of 2.50 . This revealed that the skills acquired by undergraduates in entrepreneurship education will be relevant to self-employment. While item 17, indicated a low extent of the skill acquired by undergraduates in entrepreneurship education.

\section{Hypothesis}

There is no significant difference between University of Benin and Delta State University undergraduates on their views about entrepreneurship education and career development. 
Table 5. T-test analysis of University of Benin and Delta State University undergraduates views on entrepreneurship education and career development

\begin{tabular}{lllllll}
\hline Variable & N & X & SD & DF & t-cal & Sig. \\
\hline University of Benin Undergraduates & 75 & 40.15 & 6.21 & 148 & 2.322 & 0.022 \\
Delta State University Undergraduates & 75 & 39.99 & 5.13 & & & \\
\hline
\end{tabular}

Table 5, showed the t-calculated value of 2.322 and a p-value of 0.022 . Testing at an alpha level of 0.05 , the p-value of 0.022 was less than the alpha level of 0.05 . Therefore, the null hypothesis which states that there was no significant difference between University of Benin and Delta State University undergraduates on their views about entrepreneurship education and career development was rejected. Therefore, it is concluded that there is a significant difference between University of Benin and Delta State University undergraduates' view of entrepreneurship education and career development of undergraduates.

\section{Discussion of Findings}

From the findings in research question I, the students are of the view that there are no enough facilities, inadequate resource persons, no adequate training and inadequate content for the course. This corroborates the work of Ifedili \& Ofoegbu (2011), Greene \& Saridakis (2007), Piltaway \& Cope (2007). Findings from research question 2, indicates a high extent of entrepreneurship education in ensuring that individuals fit into a diverse career based on skills acquired job creation. This is in line with the objectives of entrepreneurship education as cited in Ayatse (2013) who opined that entrepreneurship education would offer functional education for the youth and at the same time enable them to be self-employed and self-oriented. The third finding revealed that entrepreneurship education will provide training that will make undergraduates creative and innovative. This finding is equally in agreement with the objectives of entrepreneurship education as cited in (Ayatse, 2013) and the assertion of Haase \& Lautenschlager (2011). The finding from the fourth research question shows a high perception of the skills acquired being relevant to self-employment. This is the hallmark of entrepreneurship education. This is equally in line with finding of Wilson, Kirkal \& Marlino (2007) who opined that entrepreneurship education could increase students' interest in entrepreneurship as a career.

Hypothesis one showed that there is a significant difference in the views of the undergraduates of the University of Benin and Delta State University. This could be as a result of the differences in the methodology of training. Some universities expose students to both theory and practical aspects of the course, while some concentrate on just the theoretical aspect (Ifedili \& Ofoegbu, 2011).

\subsection{Recommendations and Implications for Counselling}

The first recommendation is that for entrepreneurship education to have its right place in the University programme, there should be adequate resource persons. This should not be limited to the Universities alone. The resource persons should be entrepreneurs in the students chosen career who are already practicing well, especially entrepreneurs involved in small and medium scale industry so as to enhance the career development of the students.

Moreover, the governments should provide funds provide for facilities if the programme is to survive. Apart from government, monies from internally generated revenue in the universities can also be used for this purpose because of its importance. Furthermore, well-meaning Nigerians and Non-Government Agencies can be approached for assistance.

As generally understood, entrepreneurship education is not a programme to be taught only in the classroom, but also in workshops, laboratories, farms and factories there should be tools to work with so as to sustain the students' interest and enhance their career development. The researchers also believe that emphasis should not be on theory but on practice. It is the belief of the researchers that entrepreneurship education should be $10 \%$ theory and $90 \%$ practical. Counsellors should be assigned to each department of the universities to ensure that undergraduates' career choices are in line with their potentials, interest and skills. This no doubt would ensure that students are well adjusted academically and satisfied with their career, and optimally contribute towards national development.

\section{References}

Adejimola, A. S., \& Olufunmilayo, T. O. (2009). Spinning off an Entrepreneurship Culture among Nigerian University Students: Prospects and challenges. Africa Business Manager, 3(1), 86-88. 
Ayatse, F. A. (2013). Driving Entrepreneurship Education in Nigeria: Issues and challenges. International Journal of Business \& Management Review, 1(4), 83-90.

Bassey, U. U., \& Olu, D. (2008). Tertiary Education and Graduate Self-Employment Potentials in Nigeria. Journal of the World Universities Forum, 1(3), 131-142.

Ekpoh, U. I., \& Edet, A. O. (2011). Entrepreneurship Education and Career Intentions of Tertiary Education Students in Akwalbom and Cross River States, Nigeria. International Education Studies, 4(1), 172-178. https://doi.org/10.5539/ies.v4n1p172

Greene, F., \& Saridikis, G. (2007). Understanding the Factors Influencing Graduate Entrepreneurship. National Council for Graduate Entrepreneurship, Birmingham.

Haase, K., \& Lautenschlager, A. (2011). The Teachability Dilemma of entrepreneurship. International Entrepreneurship and Management Journal, 7(2), 145-162. https://doi.org/10.1007/s11365-010-0150-3

Hannon, P. D. (2005). Philosophies of Enterprise and Entrepreneurship Education and challenges for higher education in UK. The International Journal of Entrepreneurship and Innovation, 6, 105-114. https://doi.org/10.5367/0000000053966876

Ifedili, C. J., \& Ofoegbu, F. (2011). Managing Entrepreneurship Education in Nigerian Universities. European Journal of Educational Studies, 3(1), 101-109.

Inegbenebor, A. U., \& Igbinomwanhia, O. R. (2011). Education, Training and Employment: Key to Africa's development. Retrieved from http:www.acadamia.edu

Jarvis, P. S. (2003). Career Management Paradigm Shift: Prosperity for citizens, wind-fall for Governments. Career Development, 3, 1-15.

Krumboltz, F. D., \& Worthingon, R. L. (1999). The School to work transition from learning theory perspective. The Career Development Quarterly, 47, 312-325. https://doi.org/10.1002/j.2161-0045.1999.tb00740.x

Ministry of Education, Finland. (2009). Guidelines for Entrepreneurship Education. Retrieved from http:content.ee-hubieu $>$ set $>$ print $>$ EE-HUB

Ojeifo, S. A. (2013). Entrepreneurship Education in Nigeria: A Panacea for Youth Unemployment. Journal of Education and Practice, 4(6), 61-67.

Paul, E. O. (2005). Entrepreneurship Education. In P. N. Ezema, E. O. Paul, B. O. Amoke, A. G. Godwin, C. A. Okwuolise, \& H. U. Eheli (Eds.), Entrepreneurship in Vocational Education. Enugu: Ozibel publishers.

Pitterway, L. A., \& Cope, J. P. (2007). Entrepreneurship Education: A systematic review of the evidence. International Journal of Small Business, 25(5), 479-510. https://doi.org/10.1177/0266242607080656

Rufai, R. A. (2010). Why we set up Entrepreneurship studies in Nigerian Universities. Retrieved from http://www.thenigerianvoice.com/news/45849/why-we-set-up-entrepreneurship-studiesinunivesities-8211.h tml

Sanders, N. K. (2003). Careers in Nursing. Retrieved from http://works.bepress.com/tracy-roberts/5/

Straby, R. (2002). Life and works by Design Elora. Retrieved from www.choidecarriere.com

Torre, J. J. (2015). Who is an Entrepreneur? Startup Basis. Retrieved from http://www.entrepreneur.com>article

Wilson, F., Kichul, J., \&Marlino, D. (2007). Gender Entrepreneurial Self-Efficacy, and Entrepreneurial career intentions: Implication of entrepreneurship education, Entrepreneurship. Theory and Practice, 1(2), 406-411. https://doi.org/10.1111/j.1540-6520.2007.00179.x

\section{Copyrights}

Copyright for this article is retained by the author(s), with first publication rights granted to the journal.

This is an open-access article distributed under the terms and conditions of the Creative Commons Attribution license (http://creativecommons.org/licenses/by/4.0/). 